\title{
КЛАСИФІКАЦІЯ ПОДАТКОВИХ ВІДНОСИН
}

Мамалуй 0.0 .

У науковій статті розглянуто основні підходи до загального процесу класифікаціі, методологічну проблематику, пов'язану із підходами до класифікації, та інструменти, які при цьому використовуються, цілі і значення класифікації як діяльності, завдяки якій формується значний пласт конкретних наукових напрацювань. Автором акцентовано увагу на варіативності проявів суспільних відносин, які свідчать про множинність критеріїв їх класифікації.

у роботі досліджено основні підходи до класифікаціі суспільних відносин за критеріями функціональної спрямованості, ступенем суб'єктної індивідуалізації, за галузевим підрозділенням, за кількісним характером суб'єктного складу. Виявлено відмінності у підходах до класифікації суспільних відносин різними авторами. Автором висловлено певні зауваження стосовно окремих критеріїв поділу, зокрема до класифікації правових відносин на основі темпорального критерію та характеру взаємозв'язків. Для диференціації податкових відносин важливим $\epsilon$ послідовний і належний підбір критеріїв, тому у контексті загальноі класифікації правових відносин розглянуто види податкових відносин і виокремлено низку їх специфічних особливостей.

3 огляду на значну видову різноманітність податкових відносин у рамках цього дослідження було визначено систему критеріїв класифікації податкових відносин. Найбільш однозначними критеріями поділу податкових відносин на види, на думку автора, $є$ функціональна спрямованість, характер норм, які регламентують податкові відносини, об'єктно-предметний критерій, критерій спрямованості інтересу, критерій цільової спрямованості. Досліджено особливості кожного із зазначених критеріїв поділу з огляду на конкретні прояви податкових правовідносин на практиці. Наявність великої кількості критеріїв класифікації податкових відносин $\epsilon$ елементом, за допомогою якого реалізується множина варіативності проявів відносин у сфері оподаткування.

Ключові слова: податкові відносини, класифікація, критерії класифікації податкових відносин.

В научной статье рассмотрены основные подходы $\kappa$ общему процессу классификации, методологическая проблематика, связанная с подходами к классификации, и инструменты, которые при этом используются, цели и значение классификации как деятельности, благодаря которой формируется значительный пласт конкретных научных наработок. Автором акцентировано внимание на вариативности проявлений общественных отношений, что свидетельствует о множественности критериев их классификации.

В работе исследованы основные подходы к классификации общественных отношений по критериям функциональной направленности, степени субъектной индивидуализации по отраслевому подразделению, по количественному характеру субъектного состава. Выявлены различия в подходах к классификации общественных отношений различными авторами. Автором высказано определенные замечания относительно отдельных критериев разделения, в частности классификации правовых отношений на основе темпорального критерия и характера взаимосвязей. Для дифференциации налоговых отношений важен последовательный и надлежащий подбор критериев, поэтому в контексте общей классификации правовых отношений рассмотрены виды налоговых отношений и выделен ряд их специфических особенностей.

Учитывая значительное видовое разнообразие налоговых отношений в рамках этого исследования было определено систему критериев классификации налоговых отношений. Наиболее однозначными критериями разделения налоговых отношений на виды, по мнению автора, является функциональная направленность, характер норм, регламентирующих налоговые отношения, объектно-предметный критерий, критерий направленности интереса, критерий целевой направленности. Исследованы особенности каждого из указанных критериев разделения, учитывая конкретные проявления налоговых правоотношений на практике. Наличие большого количества критериев классификации налоговых отношений является элементом, с помощью которого реализуется множество вариативности проявлений отношений в сфере налогообложения.

Ключевые слова: налоговые отношения, классификация, критерии классификации налоговых отношений.

The basic approaches to the general classification process, the methodological issues that are related to the approaches to classification and the tools used, the purpose and importance of classification as an activity, which forms a significant layer of specific scientific knowledge have been considered in the scientific article. The author focuses on the variability of manifestations of social relations, which testifies to the multiplicity of criteria for their classification. The main approaches to the classification of social relations by the criteria of functional orientation, the degree of subjective individualization, by branch, by the quantitative nature of subject composition and others have been explored. Differences in approaches to the classification of social relations by different authors have been revealed. The author made some remarks about particular separation criteria, in particular the classification of legal relations on the basis of temporal criteria and the nature of the relationship.

For the differentiation of tax relations, it is important to select the criteria consistently and properly, so in the context of the general classification of legal relations the types of tax relations have been considered and a number of their specific features have been highlighted. In view of the significant species diversity of tax relations, a system of criteria for the classification of tax relations has been identified in this study. According to the author, the most unambiguous criteria for the division of tax relations into types are the functional orientation, the nature of the rules governing tax relations, the object-subject criterion, the criterion of directionality of interest, the criterion of target orientation.

The peculiarities of each of these separation criteria have been examined in view of the specific manifestations of tax legal relationships in practice. The presence of a large number of criteria for the classification of tax relations is an element by which the variety of manifestations of relations in the sphere of taxation is manifested.

Key words: tax relations, classification, criteria for classification of tax relations. 
Постановка проблеми та їі актуальність. Потрібно звернути увагу на особливу варіативність податкових відносин. Комплексність податково-правового регулювання, багатостадійність податкового процесу, наявність двох рівнів нормативного регулювання (загальної та особливої частин) обумовлює можливість поділу відносин у сфері оподаткування за низкою критеріїв. Зважаючи на зазначену варіативність, важливим і необхідним для потреб науки $\epsilon$ послідовний і належний підбір критеріїв для диференціації податкових відносин.

Аналіз останніх досліджень і публікацій. Дослідженням проблеми класифікації правовідносин у теорії права присвячена значна кількість наукових праць. Зокрема, класифікації правовідносин присвячені роботи таких вчених як Л.В. Авраменко, Ю.А. Ведернікова, К.Г. Волинки, А.В. Папірної, О.В. Петришина, М.В. Цвіка та інших науковців.

Метою статті $\epsilon$ дослідження загальних аспектів класифікації суспільних відносин, одним із видів яких $\epsilon$ податкові відносини, критерії такої класифікації, а також визначення значущості та призначення класифікаційних процесів.

Виклад основного матеріалу. У загальнотеоретичному сенсі під поняттям «класифікація» потрібно розуміти розподіл явищ, предметів на групи, класи на основі їхніх спільних ознак [1]. До зазначеного визначення $\epsilon$ одне основне зауваження, що класифікація відбувається не тільки на основі пошуку спільних рис, але i шляхом визначення ознак, які дозволяють розрізнити явища або предмети. У цьому аспекті отримує свій вираз суттєва методологічна проблематика, пов'язана із підходами до класифікації, та інструменти, які при цьому використовуються.

Так, на основі пошуку ознак розрізнення відбувається поділ класифікованих предметів на відмінні групи. Коли ж ми шукаємо спільні ознаки, то провадимо групування предметів у межах конкретної класифікаційної групи. Наприклад, на основі ознак розрізнення виділяємо дві групи податкових відносин - регулятивні та охоронні податкові відносини. У свою чергу пошук спільних ознак дозволяє змістовно наповнити виокремлені протилежні класифікаційні групи.

Наприклад, на основі спільних ознак змістовно «наповнюється» група регулятивних податкових відносин - відносин із податкового обліку, відносини зі сплати податків, податкової звітності тощо і група охоронних податкових відносин - відносини забезпечувального характеру, відносини з притягнення до юридичної відповідальності порушників податкового законодавства. Таким чином, необхідно констатувати, що класифікація будь-яких об'єктів, предметів чи явищ повинна здійснюватися як шляхом пошуку спільних рис, так і з застосуванням прийомів розрізнення. Саме комплексний підхід дозволить провести якісне та послідовне підрозділення досліджуваних явищ.

Важливим $\epsilon$ визначення цілей класифікації. Класифікація конкретних явищ має своїм завданням забезпечити глибинне розуміння змістовної природи конкретних понять, адже тільки шляхом співставлення, пошуком спільних і відмінних рис можна сформувати комплексне уявлення про досліджуваний об'єкт. Підрозділення явищ за класифікаційними критеріями дозволяє більш послідовно пізнати їхній зміст. Кла- сифікація дозволяє формувати і системно-обрамлені структури, провести систематизацію внутрішньої структури конкретних явищ, визначити місце явища в системах вищого порядку (якщо явище $\epsilon$ інтегративним складником іншої системи), що дає змогу формувати багаторівневі структури.

Проведення класифікації дозволяє збагатити доктрину конкретної галузі права. Жодне фундаментальне дослідження якої-небудь наукової проблематики не обходиться без проведення класифікацій. Саме за посередництвом класифікаційної діяльності формується значний пласт конкретних наукових напрацювань. Здійснення класифікації підтверджує здатність науковця розглядати підняту ним проблематику у всій варіативності іï проявів. Загалом проведення класифікації в рамках правових досліджень має таку мету:

1) визначити змістовне наповнення конкретного поняття, проаналізувати його правову природу;

2) провести системне структурування досліджуваних понять;

3) збагатити правову доктрину в аспекті досліджуваної проблематики.

Варіативність проявів суспільних відносин дозволяє говорити про множинність критеріїв їх класифікації. У наукових джерелах із теорії держави та права пропонуються певні критерії класифікації правових відносин. Так, К.Г. Волинка пропонує такі критерії класифікації:

- за функціональним спрямуванням:

а) регулятивні відносини;

б) охоронні відносини;

- за ступенем суб'єктної індивідуалізації:

а) відносні відносини;

б) абсолютні відносини;

- за галузевим підрозділенням:

а) конституційні;

б) адміністративні;

в) цивільні;

г) кримінальні;

ґ) трудові;

д) фінансові;

- за кількісним характером суб'єктного складу:

а) прості відносини;

б) складні відносин;

- за підрозділенням прав та обов'язків:

а) односторонні відносини;

б) двосторонні відносини;

за характером волевиявлення учасників таких відносин:

а) договірні відносини;

б) відносини управлінського характеру;

- за темпоральною продовжуваністю:

а) короткотривалі відносини;

б) довготривалі відносини [2].

М.М. Россолов виділяє такі критерії поділу правових відносин:

1) залежно від характеру взаємозв'язків між суб'єктами:

а) загальні відносини;

б) конкретні відносини;

2) залежно від функцій у праві:

а) регулятивні відносини;

б) охоронні відносини;

3) за мірою конкретизації суб'єктного складу відносин: 


\section{Проблеми цивільного та господарського права}

а) відносні відносини;

б) абсолютні відносини;

4) за характером покладених на учасників таких відносин обов'язків:

а) активні відносини;

б) пасивні відносини [3].

Ю.А. Ведерніков та А.В. Папірна виділяють такі класифікаційні критерії для видового поділу врегульованих правом відносин:

1) за критеріям функціонального спрямування:

а) регулятивні відносини;

б) охоронні відносини;

2) за критерієм рівня індивідуалізації суб'єктного складу:

а) відносні відносини;

б) абсолютні відносини;

3) за галузевою специфікою: конституційні відносини, господарські відносини, цивільні відносини, цивільно-процесуальні відносини, кримінальні відносини, кримінально-процесуальні відносини, фінансові відносини, адміністративні відносини тощо;

4) за кількісними показниками суб'єктного складу:

а) прості відносини;

б) складні відносини;

5) за специфікою підрозділення прав та обов'язків між учасниками таких відносин:

а) односторонні відносини;

б) двосторонні відносини;

6) за специфікою дій, які має вчинити зобов'язаний учасник таких відносин:

а) активні відносини;

б) пасивні відносини;

7) за особливостями волевиявлення учасників відносин:

а) відносини договірного характеру;

б) відносини управлінського характеру;

8) за специфікою міжсуб'єктної взаємодії:

а) між державними органами;

б) між громадянами;

в) між державним органом і громадянином тощо.

9) за часовою характеристикою:

а) короткочасні відносини;

б) довготривалі відносини [4].

Свою класифікацію правових відносин запропонували також В.М. Кириченко та О.М. Куракін. Було сформовано таку класифікаційну систему:

1) за предметом правового регулювання:

а) конституційні відносини;

б) трудові відносини;

в) кримінальні відносини;

г) кримінально-процесуальні відносини;

ґ) цивільні відносини;

д) цивільно-процесуальні відносини;

е) адміністративні відносини тощо;

2) за функціональним призначенням:

а) регулятивні відносини;

б) охоронні відносини;

3) за специфікою волевиявлення учасників таких відносин:

а) відносини договірного характеру;

б) відносини управлінського характеру;

4) за ступенем визначеності суб' єктного складу:

а) відносні відносини;

б) абсолютні відносини;
5) за критерієм субординації в правовій регламентації:

а) матеріальні відносини;

б) процесуальні відносини;

6) за кількісним показником участі суб'єктів у таких відносинах:

а) прості відносини;

б) складні відносини;

7) залежно від специфіки розподілу прав та обов'язків між учасниками відносин:

а) односторонні відносини;

б) двосторонні відносини;

8) за часом реалізації відносин:

а) короткострокові відносини;

б) довгострокові відносини [5].

Система класифікаційних критеріїв для поділу правових відносин була запропонована М.В. Цвіком та О.В. Петришиним. Так, вчені класифікують правові відносини за такими критеріями:

1) за специфікою механізму реалізації суб'єктивних прав:

а) відносні відносини;

б) абсолютні відносини;

2) за предметом нормативного регулювання:

а) конституційні відносини;

б) адміністративні відносини;

в) трудові відносини;

г) фінансові відносини тощо;

3) за функціональною спрямованістю:

а) регулятивні відносини;

б) охоронні відносини;

4) за специфікою норм, на основі яких виникають відносини:

а) матеріально-правові відносини;

б) процесуально-правові відносини;

5) за темпоральним критерієм:

а) довгострокові відносини;

б) короткострокові відносини [6].

Загалом класифікаційні критерії $\epsilon$ відносно усталеними та визначеними. Тобто, система критеріїв підрозділення правовідносин може характеризуватися як така, що $\epsilon$ відносно уніфікованою. При цьому потрібно висловити певні зауваження стосовно окремих критеріїв поділу. Так, класифікація правових відносин на основі темпорального критерію має досить умовний характер. Такого роду підхід обумовлюється низкою чинників. По-перше, навіть найбільш типізовані правові відносини можуть розвиватися із різною інтенсивністю. По-друге, критерій темпоральної продовжуваності характеризується підвищеною мірою оціночності. Потрібно звернути увагу і на такий критерій класифікації як характер взаємозв'язків. За відповідним критерієм пропонувалося підрозділяти відносини на загальні та конкретні. У цьому випадку цілком закономірним $\epsilon$ питання: а які самі відносини $є$ загальними? Будь-які суспільні відносини мають свою чітку спрямованість (галузеву, телеологічну тощо). Це у свою чергу робить відповідний критерій класифікації дуже дискусійним.

В аспекті податкових відносин автор констатує їх значну видову різноманітність. Такі відносини можуть бути класифіковані за низкою критеріїв. При цьому в контексті такої класифікації потрібно визначити найбільш однозначні критерії поділу податкових відносин. В рамках цього дослідження було визначено систему 
критеріїв класифікації податкових відносин, до яких пропонується відносити:

1. За функціональною спрямованістю:

а) регулятивні відносини - відносини, які пов'язані із реалізацією учасниками податкових відносин належних їм прав та обов'язків;

б) охоронні відносини - відносини, які пов'язані із застосуванням мір негативного впливу на особу порушника приписів податкового законодавства.

2. За характером норм, які регламентують податкові відносини, їх можна підрозділити на:

а) матеріальні відносини - відносини, пов'язані з реалізацією прав та обов'язків;

б) процесуальні відносини - відносини, які мають чітко детермінований алгоритм свого розвитку.

3. За об'єктно-предметним критерієм податкові відносини можна диференціювати на:

а) нормативно-установчі податкові відносини;

б) відносини із виконанняподаткового обов'язкуплатника податків (відносини з обліку, сплати та звітності);

в) відносини з податкового контролю;

г) відносини забезпечувального характеру;

ґ) відносини із вирішення податкових спорів;

д) відносини із притягнення до юридичної відповідальності за порушення податкового законодавства.

4. Залежно від інтересу, на реалізацію якого спрямовані відносини, можна виокремити:

а) відносини, які мають своїм завданням забезпечити реалізацію приватного інтересу;

б) відносини, які мають своїм завданням забезпечити реалізацію публічного інтересу.

5. Залежно від цільової спрямованості розвитку податкових відносин їх можна підрозділити на:

а) відносини владно-майнового характеру;

б) відносини владно-організаційного характеру.

Критерій характеру норм, які регламентують податкові відносини. Залежності від того, які саме норми регламентують податкові відносини, їх можна підрозділити на:

а) матеріальні відносини;

б) процесуальні відносини.

Матеріальні відносини стосуються змістовного аспекту реалізації прав та обов'язків як зобов'язаного (платник податків), так і управомоченого (контролюючий орган) учасника податкових відносин. Що ж стосується процесуальних податкових відносин, то вони стосуються алгоритму реалізації відповідних прав та обов'язків. При цьому ізольовано матеріальні та процесуальні відносини не існують. Умовно протягом розвитку процесуальних відносин відбувається перманентна реалізація матеріальних відносин.

Критерій функціональної спрямованості. За відповідним критерієм автор виділяє:

а) регулятивні відносини;

б) охоронні відносини.

Регулятивні відносини мають відношення до позитивного правового регулювання податкових відносин, які пов'язанні із процедурами обліку, сплати податків і податкової звітності, податкового контролю тощо. Коли ж ідеться про охоронні відносини, то вони виникають у тому випадку, коли держава реагує, запускає механізм «корегування» на девіантну поведінку окремого учасника податкових відносин. Тобто, охоронні відносини в податковому праві здебільшого пов'язані із забезпечувальними заходами, із процедурами притягнення порушника податкового законодавства до юридичної відповідальності.

Об'єктно-предметний критерій. За цим критерієм податкові відносини можуть бути чітко поділені залежно від об'єкта або предмета таких відносин. Ці податкові відносини можуть бути підрозділені на нормативно-установчі відносини, відносини із податкового контролю, відносини із вирішення податкового спору тощо. Такого роду підрозділення податкових відносин фактично вказує на те, заради чого та з приводу чого виникають податкові відносини.

Критерій спрямованості інтересу. Інтерес, на який спрямованареалізаціяподатковихвідносини. можебути:

а) приватним;

б) публічним.

Так, податкові відносини $є$ публічними за своїм характером відносинами. Такі публічні відносини залежно від того, на реалізацією якого саме інтересу вони будуть направленні, можуть підрозділятися на приватно-орієнтовані та публічно-орієнтовані. Наприклад, якщо платник податків звертається до контролюючого органу за наданням йому індивідуальної податкової консультації, то такі податкові відносини слід розглядати як такі, що мають приватно-зорієнтований характер.

Завдання відносин із податкового консультування полягає в забезпеченні інтересів платника податків. Що ж стосується узагальнюючих податкових консультацій, то, незважаючи на той аспект, що їх надання ініціюється владним суб'єктом, переважно вони мають своїм призначенням забезпечити інтереси платника податків. Тобто. ключовою $€$ не стільки особа-ініціатора податкових відносин (приватний це або ж публічно-владний суб'єкт), скільки спрямованість таких відносин на реалізацію конкретного інтересу - публічного або ж приватного.

Податкові відносини, незважаючи на їх загальний публічний характер, не повинні орієнтуватися виключно на необхідність забезпечення реалізації публічного інтересу. Зобов' язаний суб'єкт податкових відносин (платник податків), перебуваючи і так у менш вигідному становищі, ніж контролюючий орган, повинен мати механізми забезпечення своїх інтересів в рамках публічних за своїм характером податкових відносин. Саме тому в рамках податкового права $є$ низка інститутів, які в першу чергу мають забезпечувати інтереси платника податків, захищати його від свавілля з боку суб'єкта владних повноважень (контролюючого органу). Необхідно чітко усвідомлювати, що левова частка всіх відносин, які виникають у сфері оподаткування, повинні забезпечувати реалізацію публічного інтересу. Це такі відносини як відносини зі сплати податків, податкового контролю, відносини із притягнення до юридичної відповідальності тощо. Критерій цільової спрямованості. Виходячи із критерію цільової спрямованості розвитку, податкові відносини можна класифікувати на:

а) відносини владно-майнового характеру;

б) відносини владно-організаційного характеру.

До відносин владно-майнового характеру належать податкові відносини, пов'язані зі сплатою податків та зборів, відносини забезпечувального характеру. Що ж стосується відносин владно-організаційного характеру, то ними $\epsilon$ податкові відносини з приводу податкової звітності, податкового контролю тощо. Навіть відносини 


\section{Проблеми цивільного та господарського права}

владно-організаційного характеру мають опосередковане відношення до податкових відносин із майновим складником. Однак такі два різновиди відносин (владно-майнові та владно-організаційні) автор не ототожнює.

Висновки. Податкові відносини можуть класифікуватися за низкою критеріїв. Такими критеріями $\epsilon$ функціональна спрямованість, характер норм, які регламентують податкові відносини, об'єктно-предметний критерій, критерій спрямованості інтересу, критерій цільової спрямованості. Наявність великої кількості критеріїв класифікації податкових відносин $\epsilon$ елементом, за допомогою якого проявляється множина варіативності проявів відносин у сфері оподаткування.

\section{Література}

1. Словник української мови. Академічний тлумачний словник (1970-1980). URL: http://sum.in.ua/s/klasyfikacija.

2. Волинка К.Г. Теорія держави і права. 2003. URL: https: //textbooks.net.ua/content/view/2373/31/.
3. Рассолов M.M. Теория государства и права. URL: https://stud.com.ua/82269/pravo/klasifikatsiya_pravovih_ vidnosin.

4. Ведерніков Ю.А., Папірна А.В. Теорія держави i права. URL: https://pidruchniki.com/16011013/pravo/ ponyattya_vidi_pravovih_vidnosin.

5. Кириченко В.М. Куракін О.М. Теорія держави і права. URL: https://pidruchniki.com/1584072021816/pravo/teoriya_ derzhavi_i_prava.

6. Загальна теорія держави і права : [Підручник для студентів юридичних вищих навчальних закладів] / М.В. Цвік, О.В. Петришин, Л.В. Авраменко та ін.; За ред. д-ра юрид. наук, проф., акад. АПрН України М.В. Цвіка, д-ра юрид. наук, проф., акад. АПрН України О.В. Петришина. Харків : Право, 2009. С. 337-338.

Мамалуй O. O., кандидат юридичних наук, суддя Верховного Суду 